\title{
Inflammatory response in the early prediction of severity in human acute pancreatitis
}

\author{
J A Viedma, M Pérez-Mateo, J Agulló, J E Domínguez, F Carballo
}

\begin{abstract}
The role of the inflammatory response in acute pancreatitis and its relation with the clinical course was examined. This study examined if the serial measurement of polymorphonuclear granulocyte (PMN) elastase/A1PI complex, phospholipase A catalytic activity, $\mathrm{C}$ reactive protein, and other acute phase proteins, and the protease inhibitor $\alpha_{2}$-macroglobulin, provides meaningful information for prognosis. Eighty non-consecutive patients with acute pancreatitis, classified according to their clinical outcome into mild $(n=40)$ and severe pancreatitis $(n=40)$, were followed up daily. Between 48 hours, median values of PMN-elastase, $C$ reactive protein - and most of the acute phase proteins - and phospholipase $A$ activity, were significantly higher in the severe pancreatitis group. PMN elastase shows a dynamic course and it reaches an early peak value at days $1-2$, followed by $C$ reactive protein (days 2-4) phospholipase A (day 3), and a negative peak for $\alpha_{2}-$ macroglobulin (days 4-5). PMN elastase (day 1 ) and $\mathrm{C}$ reactive protein (day 2 ) were selected by discriminant analysis as the most useful variables studied to allow the early accurate prediction of severity (sensitivity $100 \%$, specificity $95 \%$ ). Little or no predictive additional value was found for all other variables studied. These results strongly suggest a close relation between inflammatory parameters and clinical course in acute pancreatitis, and discriminant analysis of these variables provides a useful method to classify severity.

(Gut 1994; 35: 822-827)
\end{abstract}

Pathophysiology of acute pancreatitis is a very complex process, which entails the action of ischaemia reperfusion injury, ${ }^{1-3}$ intrapancreatic enzyme activation, ${ }^{4-6}$ and leucocyte infiltrate byproducts. ${ }^{7-9}$ Recent evidence suggests that mediators produced and released by activated inflammatory cells, may contribute considerably to the complications - multiorgan failure, pancreatic necrosis, sepsis, hypermetabolism and significant mortality in acute pancreatitis. ${ }^{10-12}$ This study was performed to test the hypothesis that the severity in acute pancreatitis is closely related to the intensity of local inflammatory response. ${ }^{13}$ We measured serially, on days $1-5$, in 80 patients with acute pancreatitis (40 mild, 40 severe disease) plasma concentrations of polymorphonuclear granulocyte (PMN) elastase/A1PI complex, - as a specific marker of granulocyte activation, ${ }^{14}$ - acute phase proteins - as markers of metabolic response from hepatocytes to circulating cytokines, secreted mainly by activated monocytes-macrophages (interleukin 6 , interleukin $\beta$, tumour necrosis factor $\alpha$ ), 15 phospholipase A catalytic activity - as marker of phagocytic activity in inflammation and necrosis $^{16}$ and $\alpha_{2}$-macroglobulin, the main plasma protease inhibitor - as marker of protease/protease inhibitor imbalance. ${ }^{17}$

Descriptive and explorative data analysis was made for all variables (days 1-5). By using the data obtained within 48 hours of admission, we applied discriminant function analysis to predict severity in acute pancreatitis.

\section{Methods}

PATIENTS

We studied a group of 80 non-consecutive patients, 43 men and 37 women with a median age of 58 years (range 23-89). The diagnosis of acute pancreatitis was based on typical clinical symptoms and at least a twofold increase of specific pancreatic serum enzymes (pancreatic amylase or lipase). Further inclusion criteria were a contrast enhanced computed tomography study of the pancreas or an ultrasound scan within 48 hours of hospital admission, or both. Patients were classified according to their clinical outcome into two groups: mild pancreatitis $(n=40)$ (uncomplicated or with only minor complications), and severe pancreatitis $(n=40)$ resulting in death, local pancreatic complication - abscess, pseudocyst or necrosis - or systemic complications. The cause of acute pancreatitis was gall stones in 55\%, chronic alcoholism in $17.5 \%$, and other or unknown causes in $27.5 \%$ of the patients. On admission, all patients were treated medically according to accepted methods. Necrotising pancreatitis was confirmed by laparatomy or after contrast enhanced computed tomography in 18 patients ( $45 \%$ of severe group).

In mild cases no life threatening complications were seen, whereas patients with severe disease (Table) frequently manifested respiratory insufficiency defined as $\mathrm{PaO}_{2}<60 \mathrm{~mm} \mathrm{Hg}$ (24 cases), sepsis (16 cases), consumptive coagulopathy ( 9 cases), shock (7 cases), renal failure ( 7 cases), severe hypocalcaemia ( 2 cases), and encephalopathy (2 cases). Death occurred in 11 of 40 patients with severe pancreatitis.

\section{LABORATORY TESTS}

Blood samples were collected under standard conditions. EDTA plasma and serum were 
Complications in the severe acute pancreatitis group $(n=40)$ *

\begin{tabular}{|c|c|c|c|c|c|c|}
\hline \multirow[b]{2}{*}{ Complication } & \multirow[b]{2}{*}{$\begin{array}{l}\text { Cases (n) } \\
(M / F)\end{array}$} & \multirow[b]{2}{*}{ Cause } & & \multicolumn{3}{|c|}{ Median value } \\
\hline & & & & Age (y) & $\begin{array}{l}E L A S_{1}{ }^{\star \star} \\
(\mu g / l)\end{array}$ & $\begin{array}{l}C R P_{2}^{\star \star} \\
(\mu g /)\end{array}$ \\
\hline $\begin{array}{r}\text { Pancreatic } \\
\text { necrosis }\end{array}$ & $18(14 / 4)$ & $\begin{array}{l}\text { Gall stones } \\
\text { Alcohol } \\
\text { Idiopathic } \\
\text { Alcohol \& gall stones }\end{array}$ & $\begin{array}{l}8 \\
6 \\
2 \\
2\end{array}$ & 50 & 448 & 170 \\
\hline $\begin{array}{l}\text { Respiratory } \\
\text { insufficiency }\end{array}$ & $25(18 / 7)$ & $\begin{array}{l}\text { Gall stones } \\
\text { Alcohol } \\
\text { Idiopathic } \\
\text { Alcohol \& gall stones }\end{array}$ & $\begin{array}{r}12 \\
7 \\
4 \\
2\end{array}$ & 58 & 504 & 157 \\
\hline Sepsis & $16(14 / 2)$ & $\begin{array}{l}\text { Gall stones } \\
\text { Alcohol } \\
\text { Mixed }\end{array}$ & $\begin{array}{l}9 \\
5 \\
2\end{array}$ & 60 & 510 & 153 \\
\hline Coagulopathy & $9(6 / 3)$ & $\begin{array}{l}\text { Gall stones } \\
\text { Alcohol } \\
\text { Mixed }\end{array}$ & $\begin{array}{l}6 \\
2 \\
1\end{array}$ & 67 & 366 & 151 \\
\hline Shock & $7(4 / 3)$ & $\begin{array}{l}\text { Gall stones } \\
\text { Alcohol }\end{array}$ & $\begin{array}{l}6 \\
1\end{array}$ & 69 & 374 & 178 \\
\hline Renal failure & $7(3 / 4)$ & $\begin{array}{l}\text { Gall stones } \\
\text { Idiopathic }\end{array}$ & $\begin{array}{l}5 \\
2\end{array}$ & 58 & 366 & 167 \\
\hline Death & $11(5 / 6)$ & $\begin{array}{l}\text { Gall stones } \\
\text { Alcohol } \\
\text { Idiopathic } \\
\text { Mixed }\end{array}$ & $\begin{array}{l}8 \\
1 \\
1 \\
1\end{array}$ & 67 & 366 & 188 \\
\hline
\end{tabular}

*A more detailed table containing a list of individual clinical features in the severe acute pancreatitis group is available upon request, $\star \star$ untransformed values of PMN elastase (day 1 ) and CRP (day 2) distribution. The application of square root transformation (SQR) of variables was used to make dispersions more homogeneous and to ensure the normal distribution of data. Data are given as medians and quartiles. To determine statistically differences $(p<0.05)$ between the median values, the two tailed Mann-Whitney U test was used.

\section{Predictive analysis}

Stepwise discriminant function analysis was applied to the data obtained within 48 hours of admission to predict the severity of acute pancreatitis. Furthermore age, sex, cause of acute pancreatitis, and the increment value of all variables assayed (value at day 2 minus value at day 1) were considered. The analysis was carried out using the BMDP statistical package (BMDP P7, 1988). If $\mathrm{x}_{1}, \mathrm{x}_{2}, . ., \mathrm{x}_{\mathrm{k}}$ are discriminating variables for mild and severe acute pancreatitis, the procedure establishes a linear function (discriminant function)

$$
\mathrm{z}=\mathrm{c}_{1} \mathrm{x}_{1}+\mathrm{c}_{2} \mathrm{x}_{2}+\ldots+\mathrm{c}_{\mathrm{k}} \mathrm{x}_{\mathrm{k}}
$$

in which $\mathrm{z}$ is the score of the discriminant function for each case and $c$ the weighing coefficient. The method used to select the discriminating variables and to determine the coefficients $c_{1}, c_{2}, \ldots c_{k}$ develops in successive steps. With each step, a variable that is shown to have the greatest disciminating power, is included in the discriminant function. Variables that do not contribute significantly (at the $5 \%$ probability value) to the final equation are subsequently excluded from the model.

The discriminant function transforms the data on each patient into a score ( $z$ value) that can be plotted as a point on a straight line. To classify optimally a new patient as a case of severe or mild acute pancreatitis, a cut off value of $z$ is established by considering the prevalence of severe $(0 \cdot 1)$ and mild (0.9) acute pancreatitis and the cost of erroneous classification (classification rule). trations of $\mathrm{C}$ reactive protein were measured by an automated particle enhanced nephelometric immunoassay (Behringewerke AG, Marburg, Germany). Antichymotrypsin and inter $\alpha$ trypsin inhibitor were measured by turbidimetry by using commercially available specific antibodies (Dakopatts, Denmark). $\alpha_{2}$-Macroglobulin, $\alpha_{1}$ protease inhibitor, and $\alpha_{1}$ acid glycoprotein were measured by nephelometry (Technicon reagents, Tarrytown NY, USA).

Blood samples from 150 healthy adults of both sexes, aged between 20 and 80 years, were used to establish a reference interval for the laboratory parameters tested.

\section{STATISTICAL ANALYSIS}

Preprocessing of data and exploratory analysis Descriptive and exploratory analysis for all variables measured on days $1-5$ in both groups of patients with acute pancreatitis was made. Multiple box and whisker plots were used. Plots synthesised information on central values (median), dispersion of variables (quartiles), and asymmetry with respect to normal

\section{Results}

SINGLE VARIABLE ANALYSIS

\section{PMN elastase}

The median peak value for PMN elastase/A1PI complex in the two groups of acute pancreatitis was reached early on days 1-2 (Fig 1). On day 1, PMN elastase values were significantly 


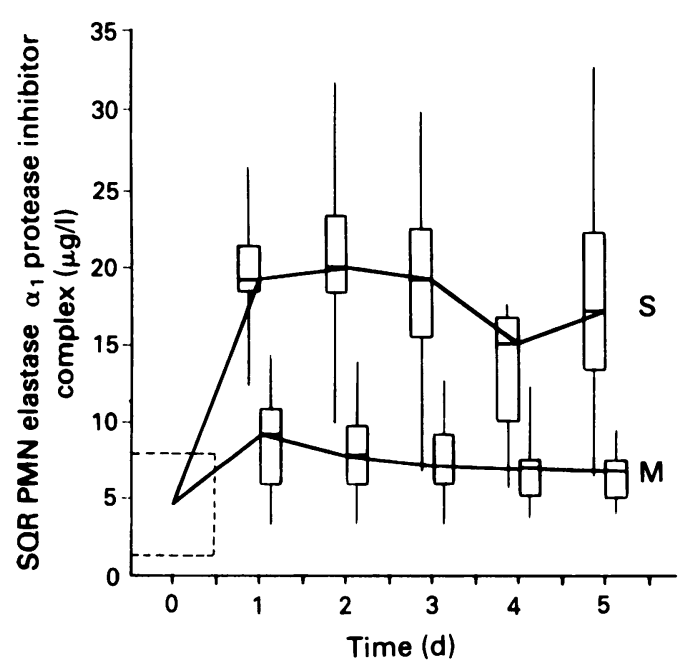

Figure 1: Multiple box and whisker plot of PMN elastase during the days 1-5 after the stay in hospital. Broken lines represent the upper and lower limit (interval 95\%) of the reference group. $M=$ mild acute pancreatitis; $S=$ severe acute pancreatitis.

higher $(\mathrm{p}<0.00001)$ in patients with severe disease $(380,304 \cdot 5-499.5 \mu \mathrm{g} / \mathrm{l}$, median and quartiles) compared with patients with mild disease $(79 \cdot 5,34.5-117 \mu \mathrm{g} / \mathrm{l}$, median and quartiles). In all patients, elastase concentrations decreased continuously during the following days. Median plasma concentrations on days 1-5 were significantly higher $(p<0.00001)$ in patients with severe disease than in those with mild pancreatitis. Values for PMN elastase $>200 \mu \mathrm{g} / \mathrm{l}$, on day 1 were exclusively found in the group of severe pancreatitis.

\section{Acute phase proteins}

In individual patients, $C$ reactive protein reaches the peak within days $2-4$, with values considerably higher and persisting for longer in the group of severe pancreatitis.

The median peak value of $C$ reactive protein was reached on day 3 in patients with severe pancreatitis $(222,141.5-303 \mathrm{mg} / \mathrm{l}$, median and quartiles) and on day 2 in patients with mild disease $(81,34-130 \mathrm{mg} / \mathrm{l}$, median and quartiles (Fig 2). Median concentrations on days $1-5$ were significantly higher $(p<0.0001)$ in patients with severe disease than those with

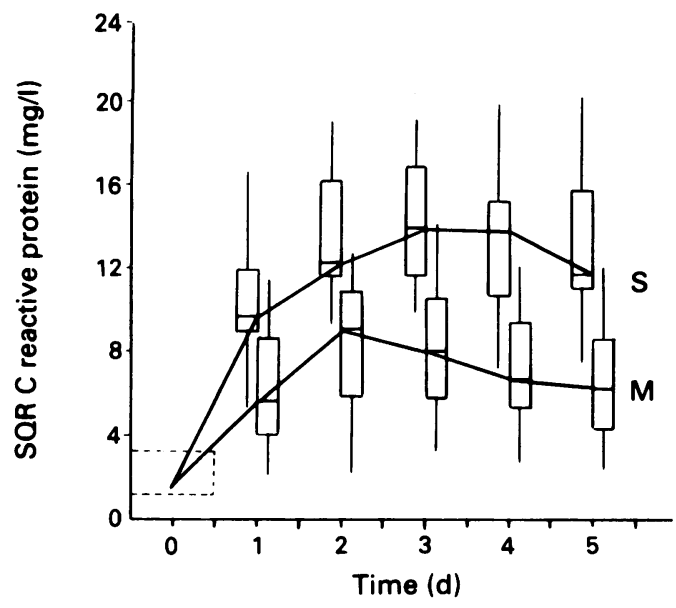

Figure 2: Time course of $C$ reactive protein.

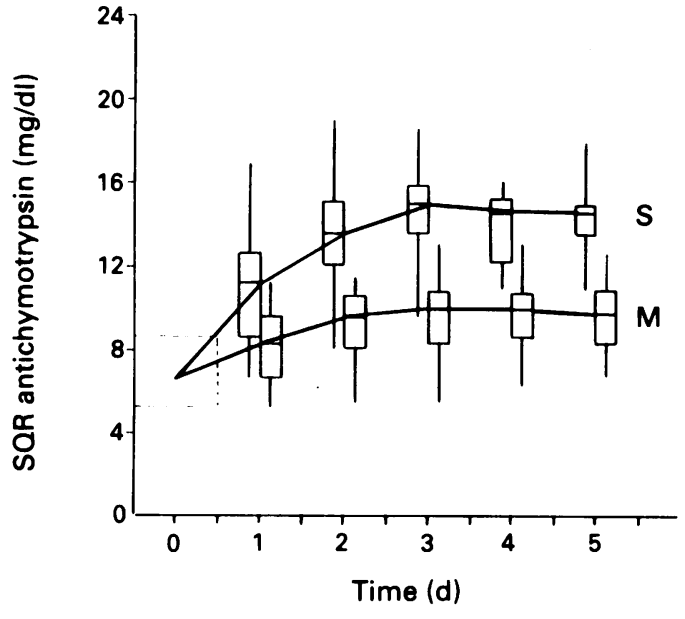

Figure 3: Time course of antichymotrypsin.

mild pancreatitis. Values for $\mathrm{C}$ reactive protein $>300 \mathrm{mg} / \mathrm{l}$ were found exlusively in the group of severe pancreatitis.

The median peak value of antichymotrypsin was reached on day 3. Antichymotrypsin concentration shows a time course slower than those showed by $\mathrm{C}$ reactive protein, on days 1-5 (Fig 3). Median concentrations on days 1-5 were significantly higher $(p<0.00001)$ in patients with severe disease than in those with mild pancreatitis. Within 48 hours, values for antichymotrpysin $>140 \mathrm{mg} / \mathrm{dl}$ were found in $80 \%$ of patients with severe acute pancreatitis.

The concentration of $\alpha$ protease inhibitor increased during the pancreatic attack in both groups, but peaked earlier in patients with mild disease (at day 2) than in those with severe disease (at day 4) (Fig 4). Median values at day 4 were significantly higher $(p<0.0001)$ in patients with severe disease compared with those with mild pancreatitis. The median peak value of $\alpha_{1}$ acid glycoprotein was reached late on day 4 .

In contrast with other acute phase proteins that increased during inflammatory response, the concentration of inter $\alpha$ trypsin inhibitor a single polypeptide chain molecule very sensitive against proteolytic enzymes - tended to decrease, particularly in patients with severe pancreatitis. In patients with mild pancreatitis,

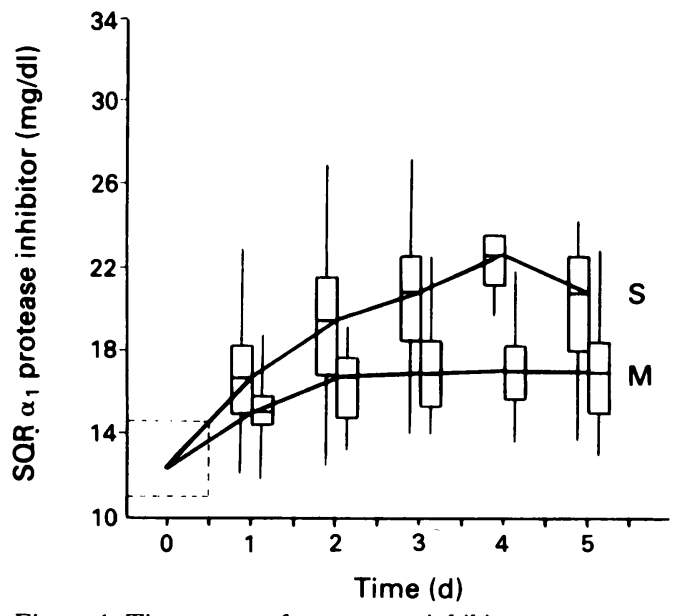

Figure 4: Time course of $\alpha_{1}$ protease inhibitor. 


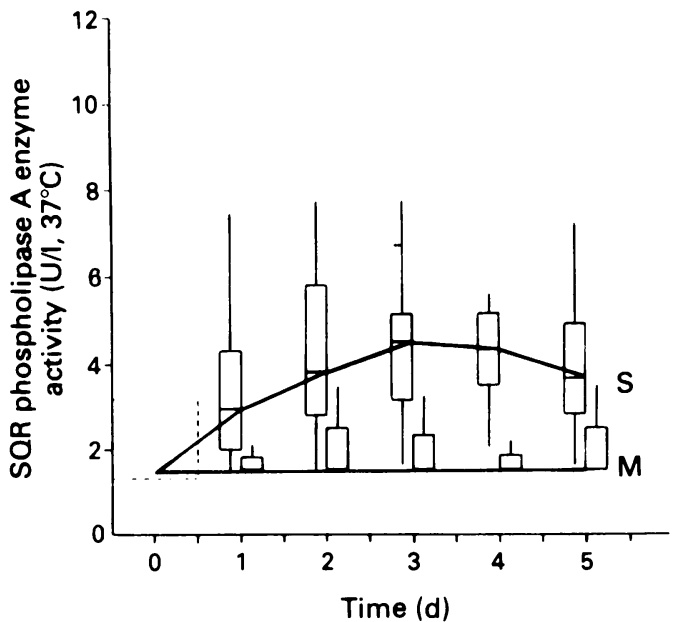

Figure 5: Time course of phospholipase A catalytic activity.

median inter $\alpha$ trypsin inhibitor concentrations remained constant during the study period, while patients with severe disease showed a continuous decrease with a minimum on day 4. As expected, the values of several of the acute phase proteins were highly correlated. On day 1 , serum concentration of $\mathrm{C}$ reactive protein was correlated with antichymotrypsin $(r=0 \cdot 708), \alpha_{1}$ acid glycoprotein $(r=0.492)$, or $\alpha_{1}$ protease inhibitor $(r=0.568)$ concentration. Furthermore, a highly significant correlation between serum concentrations of $\mathrm{C}$ reactive protein and phospholipase $A$ values on day 1 $(r=0.582 ; \mathrm{p}<0.0001)$ was found.

\section{Phospholipase $A$ activity}

The serum phospholipase A concentrations rose to high values in patients with severe disease, especially in those with necrotising pancreatitis, respiratory insufficiency, shock or sepsis. In the group of patients with severe disease, the median peak value was reached on day 3 (Fig 5). The difference in serum phospholipase A activities between patients with mild and severe pancreatitis was significant $(p<0.00001)$ on days 1-5. Using a phospholipase A cut off value of $15 \mathrm{U} / 1$ (day 3) to classify pancreatitis as severe or mild, sensitivity was $62 \%$ and specificity $94 \cdot 8 \%$.

\section{$\alpha_{2}-$ Macroglobulin}

In patients with mild pancreatitis, median $\alpha_{2}-$ macroglobulin concentrations remained constant, while patients with severe disease showed a continuous fall with a minimum at day 5. Significant differences $(p<0.00001)$ between median $\alpha_{2}$-macroglobulin values in both groups were seen on days 3-5 (Fig 6).

\section{DISCRIMINANT MULTIVARIATE ANALYSIS}

Only those cases with complete data sets for all variables were entered in the model. Eight cases with extremely atypical data, .most of whom presented very high values of PMN elastase and no available or missing values were excluded. Thus, 32 cases were included in the severe group and 40 in the mild group.
PMN elastase on day 1 was the most discriminating variable selected in the first step. This assay predicted disease severity with a sensitivity of $84 \%$. The outcome (mild or severe disease) was correctly predicted by PMN elastase assay in $93 \%$ of cases. In the second step, serum concentration of $C$ reactive protein on day 2 was selected. The discriminant function gave a sensitivity of $96.8 \%$, while correctly categorising $98.6 \%$ of cases. No more useful additional information was obtained using other variables. The classification function obtained was: $\mathrm{z}=0.46477$ (SQR) (C reactive protein (day 2)) +0.78009 (SQR) (PMN elastase (day 1)) - 16.31885 (classification rule, $\mathrm{z} \geq 0$ : severe acute pancreatitis; $\mathrm{z}$ $<0$ : mild acute pancreatitis).

We set a cut off to maximise sensitivity (that is, detection of severe cases) and specificity (optimisation of the classification function) by considering the cost of erroneous classification for severe acute pancreatitis and the prevalence for each group (mild $0 \cdot 9$, severe $0 \cdot 1)$. Therefore, the new function was: $\mathrm{z}=0.46477$ (SQR) (C reactive protein (day $2))+0.78009$ (SQR) (PMN elastase (day 1)) - 15.57958 (classification rule, $\mathrm{z} \geq 0$ : severe acute pancreatitis; $\mathrm{z}<0$ : mild acute pancreatitis).

For this function, sensitivity was $100 \%$, specificity $95 \%$, and the outcome was correctly predicted in $97 \cdot 2 \%$ of cases. Both variables selected by the model were not correlated $(r=-0.0262)$ and their courses are fully independent.

\section{Discussion}

Recent experimental and clinical data have shown that excessive activation and systemic release of endogenous humoral mediators produced by inflammatory cells - polymorphonuclear neutrophils monocytes, and macrophages - may themselves be responsible for severe complications seen in acute pancreatitis, such as adult respiratory distress syndrome, multiorgan failure, and clinical sepsis syndrome. ${ }^{20-22}$ In early phases of local inflammation, chemotactic factors activate polymorphonuclear neutrophils (the first line

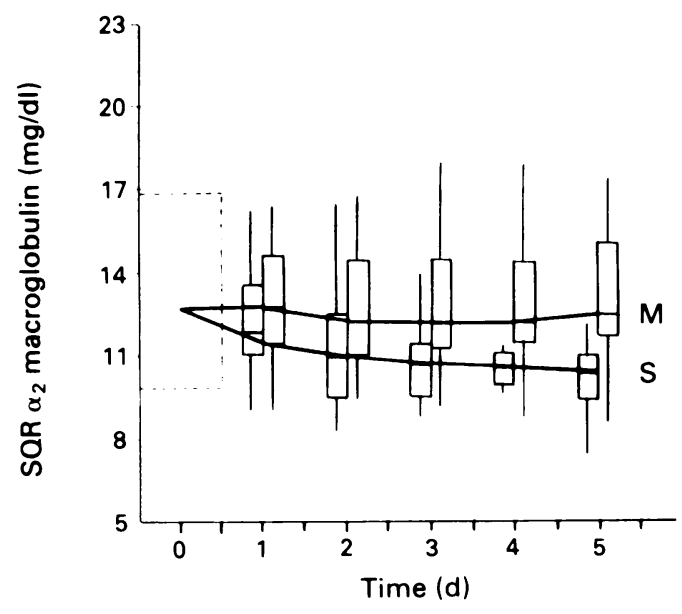

Figure 6: Time course of $\alpha_{1}$ macroglobulin. 
of cellular response) and monocytes. At the site of inflammation, these cells release biologically active products, such as proteolytic enzymes, reactive oxygen metabolites, vasoactive substances, and cytokines (tumour necrosis factor $\alpha$, interleukin 1 , interleukin 6 , interleukin 8. ${ }^{7-9} 132324$

In this study, blood concentrations of different inflammatory markers were determined to assess whether or not the intensity of inflammatory response was correlated with the severity of pancreatitis, and to obtain a reliable model for an early and accurate prediction of prognosis.

Granulocyte elastase has been shown to be a sensitive and specific marker for the early identification of inflammation, activation of granulocytes, and the predition of inflammatory complications. ${ }^{14} 18$ In this study, granulocyte elastase was the most useful marker of severity and our results coincide with those of other authors who found higher values in patients with necrotising acute pancreatitis ${ }^{25}$ or severe disease 112426 than in patients with mild disease. The time course of granuolocyte elastase showed an early peak on days 1-2 showing that polymorphonuclear neutrophils become highly activated in the early stages of acute pancreatitis. This assay predicted disease severity with a sensitivity of $84 \%$. Increased concentrations of PMN elastase were clearly associated with a poor prognosis. The PMN elastase was measured in this study by using the IMAC elastase assay (E Merck) (automated version) in plasma EDTA samples. This method correlates well with the previous sandwich enzyme linked immunosorbent assay (ELISA), and it shows satisfactory precision at the clinical decision value. The IMAC elastase performed automatically on clinical chemistry analysers, provides a fast (about 10 minutes) routine method for measurement of PMN elastase concentrations in human plasma. A negative aspect of the kit is their excessive large presentation, particularly if the elastase determination is exclusively used as an aid to clinical evaluation of acute pancreatitis. In this respect, the development by the manufacturer of several kits with different presentations is welcome. Another important concern is related to the nature of the analyte - plasma must be separated carefully from blood within 60 minutes after specimen collection to prevent interference by leakage of elastase from leucocytes.

The increased serum concentrations of C reactive protein in patients with acute pancreatitis is a consequence of activation of the monocyte-macrophage system ${ }^{15} 2729$ The median peak value of $\mathrm{C}$ reactive protein was reached later (on days 2-4) reflecting the synthesis of acute phase proteins in the liver, secondary to the release of cytokines by activated monocyte-macrophages.

Stepwise discriminant function analysis selected PMN elastase value on day 1 and C reactive protein on day 2 as the optimal combination for predicting the severity in acute pancreatitis with $100 \%$ sensitivity and $95 \%$ specificity. Both variables were fully independent $(r=-0.0262)$ and no useful additional information was obtained from all other parameters studied. The time course of acute phase proteins, phospholipase A catalytic activity, and $\alpha_{2}$-macroglobulin was similar to that described by others. $11172527-31$.

In summary, two biochemical assays easily performed routinely in most hospitals - that is, PMN elastase and $C$ reactive protein - permit the establishment at an early stage of actual inflammatory response and predict accurately the clinical course of acute pancreatitis.

Supported by DGICYT Grant PM 89-0154 from the Ministry of Education and Science, Spain. We thank Marta Pulido, MD for editorial assistance and copy editing

1 Welbourn CRB, Goldman G, Paterson IS, Valeri CR, Shepro D, Hechtman HB. Pathophysiology of ischaemia reperfusion injury: central role of neutrophil. $\mathrm{Br} \mathcal{F}$ Surg 1991: 78: $651-5$.

2 Schoemberg MH, Büchler M, Beger HG. Lipid peroxidation products in the pancreatic tissue of patients with acute pancreatitis. Br $\mathcal{F}$ Surg 1988; 75: 1254 .

3 Braganza JM, Rinderknecht $\mathrm{H}$. Free radicals and acute pancreatitis. Gastroenterology 1988; 94: 1111-2.

4 Nagai H, Henrich H, Wünsch P-H, Fischbach W, Mössner J. Role of pancreatic enzymes and their substrates in autodigestion of the pancreas. In vitro studies with isolated autodigestion of the pancreas. In vitro studies with isolated

5 Lasson A. Acute pancreatitis in man. A clinical and biochemical study of pathophysiology and treatment. Scand F Gastroenterol 1984; 19: (suppl 99): 1-57.

6 Gudgeon AM, Heath D, Hurley P, Jehanli A, Patel G, Wilson C, et al. Trypsinogen activation peptides assay in the early prediction of severity of acute pancreatitis. Lancet 1990; i: 4-8.

7 Varani J, Ginsburg I, Schuger L, Gibbs DF, Bromberg J, Johnson $\mathrm{KJ}$, et al. Endothelial cell killing by neutrophils. Synergistic interaction of oxygen products and proteases. Am $\mathcal{F}$ Pathol 1989; 135: 435-8.

8 Weiss SJ. Tissue destruction for neutrophils. $N$ Engl $\mathcal{F}$ Med 1989; 320: 365-76.

9 Fantone JC, Ward PA. Role of oxygen-derived free radicals and metabolites in leukocyte-dependent inflammatory and metabolites in leukocyte-dependent inflions.

$10 \mathrm{McF}$ adden DW. Organ failure and multiple organ system failure in pancreatitis. Pancreas 1991; 6: S37-43.

11 Gross V, Schölmerich J, Leser H-G, Salm R, Lausen M Rückauer $\mathrm{K}$, et al. Granulocyte elastase in assessment of severity of acute pancreatitis. Comparison with acute-phase proteins C-reactive protein, $\alpha_{1}$-antitrypsin, and protease
inhibitor $\alpha_{2}$-macroglobulin. Dig Dis Sci 1990; 35: 97-105.

12 Anderson BO, Bensard DD, Harken AH. The role of platelet activating factor and its antagonist in shock, sepsis and multiple organ failure. Surg Gynecol Obstet 1991; 172: 415-24.

13 Rinderknecht H. Fatal pancreatitis, a consequence of excessive leucocyte stimulation? Int $\mathcal{f}$ Pancreatol 1988; 3: 105-12.

14 Jochum M, Duswald KH, Neumann S, Witte J, Fritz $H$, Seemüller U. Proteinases and their inhibitors in inflammation: basic concepts and clinical implication. In Katunuma N, Unezawa V, Holzer H, eds. Proteinase inhibitors, medical and biological aspects. Berlin-Heidelberg. Springer-Verlag, 1983; 85-9.

15 Leser H-G, Gross V, Scheibenbogen C, Heinish A, Salm R Lausen $\mathrm{M}$, et al. Evaluation of serum interleukin-6 concentration precedes acute-phase response and reflects severity in acute pancreatitis. Gastroenterology 1991; 101: 782-5.

16 Schmidt D, Hoffmann GE. Activity of phospholipase A compared in serum of patients with pancreatic and compared in serum of patients with pancreatic

17 Banks RE Evans SW, Alexander D, Van Leuven F, Wicher JT, McMahon MJ. Alpha ${ }_{2}$ macroglobulin state in acute pancreatitis. Raised values of $\alpha_{2}$ macroblobulin-protease complexes in severe and mild attacks. Gut 1991; 32: 430-4

18 Dreher M, Gunzer G, Helger R, Lang M. An automated homogeneous enzyme immunoassay for human PMN elastase. In: Schlag G, Redl H, eds. Second Vienna shock forum. New York: Alan R, Liss, 1989; 707-10.

19 Hoffmann GE, Neumann U. Modified photometric method for the determination of phospholipase A activities. Klin Wochenschr 1989; 67: 106-9.

20 Goris RJA. Mediators of multiple organ failure. Intensive Care Med 1990; 16: S192-6.

21 Bone RC. The pathogenesis of sepsis. Ann Intern Med 1991; 115: 457-69.

22 Reld H, Schlag G. Pathophysiology of multiorgan failure (MOF) - proposed mechanisms. Clin Intensive Care 1990; 1: $66-7$.

23 Strieter RM, Kasahara K, Allen RM, Standiford TJ, Rolpe MW, Becker FS, et al. Cytokine-induced neutrophilMW, Becker FS, et al. Cytokine-induced neutrophil-
derived interleukin-8. Am f Pathol 1992; 141: 397-407.

24 Gross V, Leser H-G, Andreesen R, Lausen M, Farthmann EH, Ceska M, et al. Interleukin-8 (IL-8) and neutrophil activation in acute pancreatitis. Gastroenterology 1991; 100: A274. 
25 Uhl W, Büchler M, Malfertheiner P, Martini M, Beger HG. $P M N$ elastase in comparison with CRP, antiproteases and $\mathrm{LDH}$ as indicators of necrosis in acute human pancreatitis. Pancreas 1991; 6: 253-9.

26 Domínguez-Muñoz JE, Carballo F, García MJ, De Diego JM, Rábago L, Simón MA, et al. Clinical usefulness of polymorphonuclear elastase in predicting the severity of acute pancreatitis: results of a multicentre study. $B r \mathcal{F}$ Surg
1991; 78: 1230-4.

27 Wilson C, Heads A, Shenkin A, Imrie CW. C-reactive protein, antiproteases and complement factors as objective markers of severity in acute pancreatitis. $\mathrm{Br} \mathcal{F}$ Surg 1989; 76: 177-81
28 Bird NC, Goodman AJ, Johnson AG. Serum phospholipase $\mathrm{A}_{2}$ activity in acute pancreatitis: an early guide to severity. Brf Surg 1989; 76: 731-2.

29 Puolakkainen P, Valtonen V, Paananen A, Schröder T. $C$-reactive protein (CRP) and serum phospholipase $A_{2}$ in the assessment of the severity of acute pancreatitis. Gut the assessment of the

30 Büchler M, Malfertheiner $P$, Schädlich $H$, Nevalainen TJ, Friess H, Beger HG. Role of phospholipase $A_{2}$ in human acute pancreatitis. Gastroenterology 1989; 97: 1521-6.

31 Vadas P, Pruzansky W, Stefanski E, Sternby B, Mustard R, Bohnen $\mathrm{J}$, et al. Pathogenesis of hypotension in septic shock: correlation of circulating phospholipase $\mathrm{A}_{2}$ levels with circulatory collapse. Crit Care Med 1988; 16: 1-7. 